\title{
INTIMATIONS OF FEDERAL REMOVAL JURISDICTION IN LABOR CASES: THE PLEADINGS NEXUS
}

Federal jurisdiction over labor cases continues to grow, overreaching perhaps its designated sphere. That sphere is described in part by section 301(a) of the Labor Management Relations Act, ${ }^{1}$ which gives federal courts jurisdiction to decide suits imvolving "contracts" between employers and unions, or between unions. Recently, the Supreme Court held in United Association of Journeymen v. Local 334, United Association of Journeymen ${ }^{2}$ that, for purposes of invoking federal jurisdiction over an intra-union labor dispute removed from state court, a union constitution is a contract within the meaning of section 301. In dissent, Justice Stevens observed, "This case is important not because of its unremarkable holding that a union constitution is a contract but because the case is a striking example of the easy way in which this Court enlarges the power of the Federal Government-and the Federal Judiciary in particular-at the expense of the States." 3

It is a short step from creating federal removal jurisdiction over a state case concernimg a union constitution to creating federal removal jurisdiction over other disputes tangentially involving collective bargaining-over, for example, a union inember's state cause of action against his employer for back wages. ${ }^{4}$ The questions raised by such cases are how firm a foundation federal jurisdiction requires and how amenable a federal court should be to imputing federal elements to a complaint pleaded as a state cause of action. Increasingly, federal courts have been willing to abandon the traditional touchstones of ju-

1. Labor Management Relations (Taft-Hartley) Act § 301(a), 29 U.S.C. § 185(a) (1976) [heremafter cited as section 301]. This section provides:

Suits for violation of contracts between an employer and a labor organization representing employees in an industry affecting commerce as defined in this chapter, or between any such labor organizations, may be brought in any district court of the United States having jurisdiction of the parties, without respect to the amount in controversy or without regard to the citizenship of the parties.

2. 101 S. Ct. 2546 (1981). For a discussion of this case see notes $94-100,111-13$ and accompanying text infra.

3. $101 \mathrm{~S}$. Ct. at 2559 n.13 (Stevens, J., dissenting).

4. Compare Talbot v. National Super Mkts., 372 F. Supp. 1050 (E.D. La. 1974) (allowing removal of state court claim for back wages), discussed at notes 122-23 infra and accompanying text, with Lambright v. Red Ball Motor Freight, Inc., 335 F. Supp. 28 (W.D. La. 1971) (remanding to state court employees' claims for back wages), discussed at notes 120-21 infra and accoinpanying text. 
risdictional determinations in order to foster national labor law, and, increasingly, plaintiffs' labor suits have been removed froin state to federal courts. In other situations the well-pleaded coinplaint rule ${ }^{5}$ might be expected to insulate froin reinoval the plaintiff who has not pleaded a federal claim, much less pleaded it well. In labor disputes, however, that insulation is often illusory.

In enacting section 301 , Congress intended to eliminate procedural impediments to breach of labor contract suits against unincorporated labor unions in federal courts. ${ }^{6}$ In Textile Workers Union v. Lincoln Mills ${ }^{7}$ the Supreme Court held that the provisions of section 301 are substantive and authorize federal courts to formulate a body of federal common law over labor disputes. Since Lincoln Mills, federal jurisdiction under section 301 has expanded steadily, both in regard to what constitutes a "contract" within the ineaning of the section ${ }^{8}$ and in regard to the parties that may invoke federal jurisdiction under this section. ${ }^{9}$

5. The well-pleaded complaint rule requires that the complaint, unaided by the answer or by a petition for removal, show that a federal controversy underlies the cause of action before federal jurisdiction can be imvoked. See Gully v. First Nat'l Bank, 299 U.S. 109 (1936); Tennessce v. Union \& Planters' Bank, 152 U.S. 454 (1894). Justice Clarke, writing for the Supreme Court in Great Northern Ry. Co. v. Alexander, 246 U.S. 276 (1918), noted:

The obvious principle . . . is that, in the absence of a fraudulent purpose to defeat removal, the plaintiff may by the allegations of his coinplaint determine the status with respect to renuovability of a case, arising under a law of the United States, when it is commenced, and that this power to determine the removability of his case continues with the plaintiff throughout the litigation, so that whether such a case non-removable when commenced shall afterwards beconie removable depends not upon what the defendant may allege or prove or what the court may, after hearing upon the merits, in invitum, order, but solely upon the form whicl the plaintiff by his voluntary action shall give to the pleadings im the case as it progresses towards a conclusion. Id. at 282.

6. S. ReP. No. 105, 80th Cong., 1st Sess. 15-16 (1947), reprinted in SENATE CoMM. ON LAbor \& Public Welfare, 93d Cong., 2D Sess., Legislative History of the labor MaNageMENT RELATIONS ACT, 1947, at 421-22 (1974). See Keene, The Supreme Court, Section 301 and No-Srike Clauses: From Lincoln Mills 10 Avco and Beyond, 15 VILL. L. REv. 33, 34 (1969). For an overview of the statutory predecessor to section 301, see Isbrandtsen Co. v. District 2, Marine Eng'rs Beneficial Ass'n, 256 F. Supp. 68, 75-76 (E.D.N.Y. 1966).

7. 353 U.S. 448 (1957).

8. See, e.g., Umited Ass'n of Journeymen v. Local 334, United Ass'n of Journeymcn, $101 \mathrm{~S}$. Ct. 2546 (1981), discussed at notes 94-101 infra and acconupanying text; Shceran v. General Elee. Co., 593 F.2d 93, $98-99$ (9th Cir.), cert. denied, 444 U.S. 868 (1979) (pension plan was an "imtcgral part" of collective bargaining agreement), discussed at text accompanying notes 107-08 infra; Klepacky v. Kraftco Corp., 80 L.R.R.M. 3144 (D. Coun. June 5, 1972) (an oral promise to employees "merged" into the collective bargaining agreement), discussed at text accompanyimg notes 102-04 infra.

9. Although section 301 refers specifically to actions between employers and labor umions, it has been held to give employees the right to sue individually. See Smith v. Evening News Assoc., 371 U.S. 195 (1962). A district court lias even gone so far as to extend the scope of section 301 to create a cause of action for an employer against his individual employee. See New York State United Teachers v. Thompson, 459 F. Supp. 677 (N.D.N.Y. 1978). For discussious of Thompson, 

a complaint to determine its real nature, ${ }^{16}$ the limits of such discretion are unclear. Taken as a whole, the numerous recent labor cases addressing this issue form no seamless web of jurisprudence, but rather show the jurisdictional tangles that result when federalism confronts the need for a uniform national labor policy. Focusing on recent state causes of action that defendants have sought to remove to federal forums, this comment outlines the elements necessary for a cause of action to arise under section $301^{17}$ and explores the courts' willingness to look beyond complaints to find these elements. The comment concludes with a plea for greater jurisdictional certainty by closer adherence to the well-pleaded complaimt rule. ${ }^{18}$

\section{BACKGROUND: REMOVAL}

Simce 1887 removal jurisdiction has been tied explicitly to the requirements of original jurisdiction: ${ }^{19}$ the case to be removed must be "founded on a claim or right arismg under the Constitution, treaties or laws of the Umited States . . .."20 One must note, however, that the factors to be considered in determining removal jurisdiction are not interchangeable with those used in determining whether a complaimt origmally brought in federal court would have properly invoked original federal question jurisdiction. Certain considerations emerge umiquely apposite to the issue of removal: that the plaintiff is the master of his claim, ${ }^{21}$ that he las the prerogative of choosing his fo-

moval is but one aspect of the primacy of the federal judiciary in deciding questions of federal law.' "' 390 U.S. at 560 (quoting England v. Medical Examiners, 375 U.S. 411, 415-16 (1963)).

The Court in Boys Mkt., Inc. v. Retail Clerks Local 770, 398 U.S. 235 (1970), reaffirmed the Avco approach, noting that state courts practically had been ousted of jurisdiction in section 301 suits seeking to enjoin unions from striking pursuant to the terms of a collective bargaining agreement, and that otherwise, federal courts would be frustrated in achieving a uniform federal labor policy. Id. at 245 .

For further discussion of this issue, see Bartosic, Injunctions and Section 301: The Patchwork of Avco and Philadelphia Marine on the Fabric of National Labor Policy, 69 CoLUM. L. Rev. 980 (1969); Keene, The Supreme Court, Section 301 and No-Strike Clauses: From Lincoln Mills to Avco and Beyond, 15 VILL. L. Rev. 32 (1969); Lesuick, State-Court Injunctions and the Federal Common Law of Labor Contracts: Beyond Norris-LaGuardia, 79 HARv. L. Rev. 757 (1966); Note, Labor Law: Removal of Suits for Injunctive Relief Under Section 301 of the Taft-Hartley Act, 65 ColuM. L. Rev. 907 (1965); Note, Removal of and State Court Jurisdiction Over Actions Seeking to Enjoin Strikes in Violation of Collective Bargaining Agreements, 113 U. PA. L. REv. 1096 (1965).

16. See 1 J. Moore \& J. Wicker, Federal Practice ๆ 0.160, at 185-87 (2d ed. 1979).

17. See notes $55-117$ infra and accompanying text.

18. See notes 118-32 infra and accoinpanying text.

19. See Flory, Federal Removal Jurisdiction, 1 LA. L. Rev. 499, 512 (1939).

20. 28 U.S.C. $\$ 1441$ (b) (1976). For an excellent discussion and criticism of the "arising under" doctrine, see Note, The Outer Limits of "Arising Under," 54 N.Y.U.L. REv. 978 (1979). See also WRIGHT, MILlER \& COOPER, supra note $13, \S 3722$.

21. See The Fair v. Kohler Die \& Specialty Co., 228 U.S. 22, 25 (1913). 
rum, ${ }^{22}$ and that he may defeat removal by good faith avoidance of allegations that would establislı federal jurisdiction;23 that improper removal will expose the plaintiff to the risk of being forced to hitigate his claim in federal court only to liave an appellate court deny federal jurisdiction; ${ }^{24}$ that strategic advantages are likely to motivate the defendant to seek removal; 25 that state tribunals can best resolve state issues; ${ }^{26}$ that comity between federal and state courts should be pronoted and friction deterred;27 and that the overloading of federal courts sliould be avoided.28

On the other liand, one inust consider the risk that the defendant might lose his right to litigate an intrinsically federal issue in federal court. ${ }^{29}$ State courts are likely to guard federal interests less zealously than federal courts. ${ }^{30}$ Although the defendant has the possibility of obtaining review by the United States Supreme Court, that possibility is remote. $^{31}$

Antecedent to these considerations, lowever, is consideration of the plaimtiff's claim. If the plaintiff has not sued on a federal claim, the defendant has no right to be sued in a federal court. 32 A federal forum should not be ordained for every appearance of a federal eleinent in a state claim. The well-pleaded complaint rule provides a convenient rule of thumb by which jurisdiction is determined on the face of the complaint and by which cases of merely peripheral federal significance are weeded out of federal courts. ${ }^{33}$

Gully v. First National Bank ${ }^{34}$ has been instrumental in proinoting a strict interpretation of the "well-pleaded" requirement. Justice Cardozo, writing for the Supreme Court, held that removal to federal court requires that the federal claim be an essential element of the plaintiff's cause of action: "A genuine and present controversy, not inerely a pos-

22. Jones v. General Tire \& Rubber Co., 54l F.2d 660, 664 (7th Cir. 1976).

23. $I d$.

24. WRIGHT, MILLER \& COOPER, supra note 13, \& 3721, at 537.

25. See generally Summers, Analysis of Factors that Influence Choice of Forum in Diversity Cases, 47 Iowa L. Rev. 933 (1962).

26. Sce Wechsler, Federal Jurisdiction and the Revision of the Judicial Code, 13 LAW \& CoNTEMP. PROB. 216, 218 (1948).

27. See Krey Packing Co. v. Hamilton, 572 F.2d 1280, 1284 (8th Cir. 1978). 1979).

28. See People v. Glendale Fed. Savings \& Loan Ass'n, 475 F. Supp. 728,732 (C.D. Cal.

29. See Wright, Miller \& CoOPER, supra note 13, § 3721, at 537.

30. See Wechsler, supra note 26 , at 233-35.

31. See id. 218.

32. See 65 HaRv. L. Rev. 1443, 1444 (1952).

33. See Cohen, The Broken Compass: The Requirement that a Case Arise "Directly" Under Federal Law, 115 U. PA. L. REv. 890, 894 (1967).

34. 299 U.S. 109 (1936). 
sible or conjectural one . . . must be disclosed upon the face of the complaint, unaided by the answer or by the petition for removal." 35 But even in laying down these criteria for a well-pleaded complamt, ${ }^{36}$ Cardozo warned against mechanical determinations of federal jurisdiction. He urged a "common-sense accommodation of judgment to kaleidoscopic situations" in determining whether the federal controversy is basic to the claim or merely collateral. ${ }^{37}$

Commentators have criticized this distimction between "collateral" and "basic" issues as too nebulous for meaningful application. ${ }^{38}$ Some have suggested that a federal defense to a state claim should suffice to allow removal and that this approacli would better serve the purposes of federal-question jurisdiction. ${ }^{39}$ Despite this criticism, the Gully rule of strict construction of pleadings generally has persisted as the guide for determining removal jurisdiction. ${ }^{40}$ In La Chemise Lacoste v. Alligator Co. ${ }^{41}$ the Court of Appeals for the Third Circuit reiterated that the reinoval procedure "reflects a congressional policy of severe abridgement of the right to remove a state action to a federal court" and insisted that the plamtiff's imitial pleading must set fortl the basis for removal.42

When mixed state and federal claims are considered under the statutory "arising under" standard, ${ }^{43}$ lowever, the determination of federal jurisdiction is less clear-cut. ${ }^{44}$ The court must attempt to deter-

35. Id. at 113 .

36. The "well-pleaded complaint" rule actually was engendered in Gold-Washing \& Water Co. v. Keyes, 96 U.S. 199 (1877), in which the Court affirmed removal to federal court of an action involving federal regulation of water rights.

37. 299 U.S. at 118.

38. See, e.g., WRIGHT, MILLER \& COOPER, supra note 13, § 3722, at 555; Cohen, supra note 33, at 905 .

39. See ALI, Study of the Division of JuRisdiction Between State and Federal CourTs $\$ 1312$ (Tent. Draft No. 4, 1966); Moore, Problems of the Federal Judiciary, 35 F.R.D. 305,316 (1964). Such a view is as nostalgic as it is progressive. Federal courts originally allowed removal on the basis of a federal defense. See Railroad Co. v. Mississippi, 102 U.S. 135 (1880). In 1887, Congress amended the removal statute to limit removal jurisdiction to those cases that a plaintiff might have brought originally in a federal court. Act of Mar. 3, 1887, ch. 373, 24 Stat. 552, as amended by Act of Aug. 13, 1888, ch. 866, 25 Stat. 433 (current version at 28 U.S.C. 81441 (1976)). In Tennessee v. Union \& Planters' Bank, 152 U.S. 454 (1894), the Supreme Court held that under this removal provision, federal jurisdiction must be disclosed by the complaint, unaided by the answer. See Note, supra note 20 , at $992-93$.

40. See Skelly Oil Co. v. Phillips Petroleum Co., 339 U.S. 667 (1949); First Nat'l Bank v. Aberdeen Nat'l Bank, 627 F.2d 843 (8th Cir. 1980).

41. 506 F.2d 339 (3d Cir.), cert. denied, 421 U.S. 937 (1974).

42. 506 F.2d at 344 .

43. See notes 19-20 supra and accompanying text.

44. See Oneida Indian Nation v. Connty of Oneida, 414 U.S. 661 (1973), in which the Court held that federal jurisdiction existed for a possessory land claim, even though such a claim was traditionally a state cause of action. The Court pointed to the federal laws giving right to posses- 
mine the "real" nature of the claim, i.e., whether it is essentially federal irrespective of the plaintiff's characterization of it. ${ }^{45}$ Obviously, fastidious adherence to the well-pleaded complaint rule would open the door to manipulation by plaintiffs, who could circumvent federal jurisdiction of an essentially federal claim simply by omitting the federal ingredients from their pleadings. Hence, if a plaintiff pleads artfully or in bad faith to frustrate federal jurisdiction, courts will not allow the failure to plead a federal claim to defeat removal. ${ }^{46}$

Some courts have been willing to look beyond the complaint to the petition for removal to determine if a substantive issue of federal law is imvolved, ${ }^{47}$ although this practice is contrary to Cardozo's admonition in Gully. ${ }^{48}$ Fay v. American Cystoscope Makers, Inc. ${ }^{49}$ is an influential labor case permitting the petition for removal to establish federal jurisdiction. The holding in Fay, however, is narrow: where it is necessary to determine whether a labor umion is "representing employees in an industry affecting commerce" within the ineaning of section 301 , it is permissible to look to the petition for removal to establish the union's status. ${ }^{50}$ Although such a limited departure from Gully scarcely violates its spirit, the Court of Appeals for the Third Circuit in La Chemise Lacoste v. Alligator Co. ${ }^{51}$ took pains to avoid legitimizing Fay's approach. The court criticized attempts by the lower courts to "engraft exceptions contrary to the legislative policy so zealously protected by the Supreme Court."52 The court stopped short, however, of rejecting Fay's underlying rationale, which rested on the preeniptive nature of section 301.53 Whether courts inay look to petitions for reinoval to establish federal jurisdiction reinains an unresolved issue. ${ }^{54}$

sion as the basis for federal jurisdiction in satisfaction of the well-pleaded coinplaint rule. See generally Note, supra note 20, at 983-84.

45. See WrIGHT, MiLLER \& COOPER, supra note $13, \S 3721$, at 530-32 and cases collected therein.

46. Id. § 3722 , at 564 .

47. Id. 561 .

48. See text accompanying note 35 supra.

49. 98 F. Supp. 278 (S.D.N.Y. 1951).

50. Id. at 280. Accord, George D. Roper Corp. v. Local 16, Stove, Furnace \& Allied Appliance Workers, 279 F. Supp. 717 (S.D. Ohio 1968); Minkoff v. Scranton Frocks, Inc., 172 F. Supp. 870 (S.D.N.Y. 1959), aff d, 279 F.2d 115 (2d Cir. 1960). For a criticisin of Fay, see 65 HARv. L. Rev. 1443 (1952).

51. 506 F.2d 339 (3d Cir.), cert. denied, 421 U.S. 937 (1974) (vacating district court's grant of federal removal jurisdiction in suit for declaratory jndgment of trademark rights).

52. $506 \mathrm{~F} .2 \mathrm{~d}$ at 345.

53. See id. at 346. For a discussion of La Chemise Lacoste, see Note, Removal-State Declaratory Actions Based on Federal Question Jurisdiction-LaChemise Lacoste v. Alligator Co., 17 B.C. INDUS. \& COM. L. REv. 72 (1975).

54. See WriGHT, MilleR \& COOPER, supra note $13, \S 3722$, at 561 , and cases cited therein. 


\section{The Section 301 Cause of Action: Necessary Elements}

The central issue in deciding whether to allow removal via section 301 is whether the facts alleged are sufficient to establish a claim thereunder. This broad question can be divided into three parts. Is the plaintiff's cause of action contractual in nature? Does the contract fall within the purview of section 301? Are the parties to the suit appropriate for a section 301 cause of action?

\section{A. Finding a Contractual Violation.}

Section 301 requires a violation of a collective bargaining agreement before federal jurisdiction is invoked. A question may arise whether the plaintiff has in fact claimed a contractual breach. In Bradmon v. Ford Motor Co. ${ }^{55}$ for example, the plaintiff, a former Ford employee, alleged that Ford had wrongfully discharged him in retahation for his filing a workmen's compensation claim. The plaimtiff's state cause of action was founded on the recent Michigan case of Sventko v. Kroger Co. ${ }^{56}$ which had held that an "at will" employee has a state cause of action against his employer for wrongful termination. ${ }^{57}$ The plaintiff in Bradmon also asserted rights under Michigan's workmen's compensation law. The defendant successfully sought removal, alleging that federal law governed pursuant to section 301 . On its first denial of the plaintiff's motion to remand to state court, the district court summarily found that the complaint had alleged a violation of the collective bargaining agreement:

The gist of plaintiff's claim . . . is unlawful discharge. Defendant alleges . . . that plaintiff's rights with respect to wages, hours, and terms and conditions of employment are governed by the collective bargaining agreement entered into by itself and . . . plaimtiff's bargaining agent. If the discharge was unlawful, it was a violation of that agreement. Therefore, this is a suit "for violation of contracts between an employer and a labor organization representing employees in an imdustry affecting commerce. . ."; it follows that this Court has jurisdiction over the subject matter of the dispute..$^{58}$

Apparently, the court presupposed not only that the complaint sounded in contract but also that an "at will" employee has no contractual basis other than the collective bargaining agreement on which to sue, even if

55. No. 78-70913 (E.D. Mich. Nov. 14, 1980).

56. 69 Mich. App. 644, 245 N.W.2d 151 (1976).

57. Id. at $647-49,245$ N.W.2d at 153-54.

58. Bradmon v. Ford Motor Co., No. 78-70913, slip op. at 5-6 (E.D. Mich. May 30, 1978) (iirst denial of motion to remand), quoted in No. 78-70913, ship. op. at 2 (E.D. Mich. Nov. 14, 1980), appeal docketed, No. 80-1788 (6th Cir. Nov. 28, 1980). 
the employee believes he does..$^{59}$

On rehearing of his motion to remand, the plamtiff contended that his state cause of action sounded in tort, not contract. Because section 301 applies specifically to suits for violations of labor contracts, actions sounding in tort are not within its purview and hence not removable via this section. ${ }^{60}$ The court acknowledged that an employee's state claim of unlawful discharge might sound in tort, depending on how one interpreted Sventko v. Kroger Co. ${ }^{61}$ The federal court determined, however, that it should have removal jurisdiction. The court reasoned that the public policy underlying Sventko, the protection of "at will" employees, should not extend to an employee who has the protection of a collective bargaining agreement. The plaintiff therefore had no valid state cause of action, and the federal court refused to remand.62 The court also did not foreclose the alternative interpretation that the claim sounded in contract pursuant to section $301.6^{63}$ Thus the plaintiff was ousted of his state claim. Regardless of what cause of action he had

59. It is unclear from the opinion why this presupposition should be made. If one were searching for authority, one inight consider these remarks from N.L.R.B. v. Allis-Chalmers Mfg. Co., 388 U.S. 175, 180 (1967) (footnote onitted):

National labor policy has been built on the premise that by pooling their econounic strength and acting through a labor organization freely cliosen by the majority, the employees of an appropriate unit have the most effective mcans of bargaining for improvements in wages, lours, and working conditions. The policy therefore extinguislies the individual employee's power to order his own relations with his employer and creates a power vested in the chosen representative to act in the interest of all employees. . . . Thus only the union may contract the employee's terms and conditions of employment, and provisions for processing his grievances....

This authority, lowever, does not foreclose the possibility of iniphed contractual rights, the violation of whicl would not necessarily constitute a violation of the collective bargaining agreement. Nor does it foreclose the possibility of a private contract with the employer imdependent of the collective bargaining agreement.

60. Thus a truck driver's state suit against his employer for malicious arrest and prosecution, tortious interference with his labor contract, and libel was not removable to federal court, for the cause of action sounded in intentional tort, not contract. See Collins v. Sears, Roebuck \& Co., No. 80 C 3112 (N.D. Ill. Scpt. 17, 1980). Likewise, a union's state claim against non-union contractors for tortious interference with their labor agreements was held non-removable. See Furriers Joint Council v. Independent Fur Contractors Ass'n, 99 L.R.R.M. 2417 (S.D.N.Y. July 28, 1978). See also Brough v. United Steelworkers, 437 F.2d 748 (1st Cir. 1971) (state cause of action for employer's neghigence was non-removable); Sepia Trucking Co. v. International Bhd. of Teanstcrs Local 705, No. 80 C 403 (N.D. Ill. July 31, 1980) (state cause of action for tortious interference with contractual relations not removable as arguably alleging a "secondary boycott" under 29 U.S.C. § 158(b)(4)(i)(B) (1976)).

61. 69 Mich. App. 644, 245 N.W.2d 151 (1976).

62. No. 78-70913, slip op. at 6-7 (E.D. Mich. Nov. 14, 1980). But as the Court of Appeals for the First Circuit has noted, "It is . . . irrelevant that plaintiff may, in fact, liave no valid state cause of action, but at best only a federal one; le is free to select the suit he will bring." Brough $v$. United Steelworkers, 437 F.2d 748, 749 (1st Cir. 1971).

63. No. 78-70913, slip op. at 4-5. 
intended, the court could discern in his claim a seed of federal concern that had to blossoin in federal court.

The result in Bradmon seens a usurpation of state jurisdiction and, considering that the court believed the cause of action was "best understood as tort based,"64 an unjustifiable one. The significance of the case hes in the court's willingness to look not only beyond the coinplaint, but beyond section 301 itself to base federal removal jurisdiction not upon a well-pleaded complaint of a violation of a collective bargaining agreeinent but upon a doubtful characterization of the cause of action as one based on a dispute over the interpretation and enforceability of a contract. Bradmon, however, is not unique. Another court, following an equally ainorphous standard of federal jurisdiction, considered whether the complaint arose froin "the coininon nucleus of operative facts" of the collective bargaining agreement. 65 Under so broad a test it seeins likely that almost any labor-related suit brought by a party to a collective bargaining agreeinent against another party to that agreement could be thrust into federal court pursuant to section 301 .

The Court of Appeals for the Seventh Circuit has stopped short of so broad a warrant of federal jurisdiction. In Jones $v$. General Tire \& Rubber Co. ${ }^{66}$ an employee sought damages and reinstatement after he was promoted from an hourly position to a salaried position and later discharged by his employer. In state court the plaintiff asserted an implied contractual right to return to his old hourly position. The federal court could not find a basis for removal jurisdiction via section 301, though the plaintiff's complaint asserted that the implied contractual right arose partly from "negotiated collective bargaining agreeinents." 67 The court noted that the plaintiff had not asserted a violation of federal labor law in his complaint and that his alleged contractual right conld not arise under any construction of the collective bargaining agreement. 68

64. Id. at 4.

65. Chapman v. Southeast Region I.L.G.W.U. Health and Welfare Recreation Fund, 265 F. Supp. 675,678 (D.S.C. 1967) (allowing removal to federal court of action brought by non-union employees against their employer for wrongful withholding of vacation pay).

66. 541 F.2d 660 (7th Cir. 1976).

67. Id. at 661 .

68. Id. at 662-64. Cf. Adams v. Budd, 349 F.2d 368 (3d Cir. 1965) (employee claim founded on pre-collective-bargaining-agreement promise of seniority did not allege violation of collective bargaining agreement so as to be within the scope of section 301). It seems that the Jones court has gone too far in limiting federal jurisdiction. The court apparently demed federal jurisdiction because it deemed the claim based on an imphication from the contract as substantively lacking in merit. The correct disposition of such a claim would appear to be to retain removal jurisdiction and render judgment on the pleadings for the defendant. See Wheeldin v. Wheeler, 373 U.S. 647, 649 (1963); Bell v. Hood, 327 U.S. 678, 681-82 (1946). 
Similarly, when an employee sued in state court (on a cause of action based exclusively on state principles of contract law) for a breach of his employer's oral promise to proinote him to a supervisory position with higher pay, a federal court refused removal jurisdiction, even though the plaintiff was at all times subject to a collective bargaiming agreement. In a straightforward application of the well-pleaded requirement, the court refused to allow the defendant to invoke federal jurisdiction by raising the bargaining agreement as a defense. 69

Some of the uncertainty about the nature of the plaintiff's claim evolves from the fact that state courts, being courts of general jurisdiction, generally require no pleading of subject matter jurisdiction. ${ }^{70} \mathrm{Be}-$ cause the plaintiff is never required to state whether he is invoking federal jurisdiction, the federal court is compelled to read something into the complaint. If the court reads into the complaint a claim of contractual breach arising under section 301 , then federal law will preempt state law. ${ }^{71}$

Hence in Johnson v. England 72 the Court of Appeals for the Ninith Circuit allowed removal of a union's state cause of action to compel arbitration pursuant to the collective bargaining agreement: section 301(a) preempted state law claims and the plaintiff's claim was necessarily a federal one..$^{73}$ That result is consistent with the Supreme Court's view that, in contract disputes arising under section 301, "the need for a simgle body of federal law [is] particularly compelling."74 Because the plamtiff union specifically alleged a breach of the collective bargaining agreement, the claim arose under section 301(a), and federal law controlled. Thus removal properly was allowed.

69. Wolowiec v. Mogen David Wine Corp., No. 80 C 6855 (E.D. Ill. Mar. 17, 1981).

70. See F. James \& G. Hazard, Civil Procedure 613-14 (2d ed. 1977). Official Form 2(c), on the other hand, directs the plaintiff alleging federal jurisdiction founded on a particular federal statute to specify that statute in his pleading. See 5 C. Wright \& A. MILler, Federal Practice AND PROCEDURe \& 1210, at 95 (1969 \& Supp. 1981).

71. See Local 174, Teamsters v. Lucas Flour Co., 369 U.S. 95, 102 (1962) (holding that although state and federal jurisdiction are coucurrent under section 301, local law must yield to federal law in resolving an arbitration dispute arising under a collective bargaining agreement). Note that the preeinption doctrine at issue here is not the same as that involved in preempting state and federal courts of jurisdiction of claims within the jurisdiction of the National Labor Relations Board, as that doctrine was enunciated in San Diego Building Trades Council v. Garinon, 359 U.S. 236 (1959). For an analysis of the labor law preeunptiou doctrine, see Cox, Labor Law Preemption Revisited, 85 HARv. L. Rev. 1337 (1972). The Lucas Flour Court ruled that the Garmon preenption doctrine is "not relevant" to section 301 suits. 369 U.S. at 101 n.9. See also William E. Arnold Co. v. Carpenters Dist. Council, 417 U.S. 12, 16 (1974).

72. 356 F.2d 44 (9th Cir.), cert. denied, 384 U.S. 961 (1966).

73. 356 F. $2 d$ at 48.

74. 369 U.S. at 104. 
Before a court determines that federal law preempts state law by force of section 301, however, the court must determine the nature of the plaintiff's claim, i.e., whether the claim is for a violation of a collective bargaining agreement. It is not clear that a claim concerning an arbitration dispute invariably should fall within the scope of section 301(a), even if the collective bargaining agreeinent provides for arbitration. For instance, im Kallen v. District 1199, National Union of Hospital \& Health Care Employees ${ }^{75}$ an arbitrator had ordered an employer to make overdue contributions to employee benefit fund accounts. The einployer petitioned the state court to vacate the award. The umion successfully removed the suit to federal court pursuant to section 301 despite the plaintiff's contention that he had alleged no violation of a collective bargaining agreennent. The court observed that the bargaming agreement provided for arbitration of grievances and that because the employer engaged in interstate coininerce, federal law apphed to the interpretation of the contract. A contract provision made the arbitration final and binding on the parties, and the court reasoned that by participating in the arbitration, the employer implicitly had agreed "that federal court intervention may be sought to compel compliance." 76

Had this suit been an action to enforce the arbitrator's award, the result in Kallen would seem coinpelling: in a bargaining agreeinent which provides for binding arbitration, an assertion of the award is in fact an assertion of the contract and is a claim arising under federal law. Kallen is problematic, however, im that the action was to vacate the award, not to enforce it. The union sought to assert the arbitration clause as a defense. It is fundamental to the meaning of "wellpleaded" that a defendant caimot renove a suit froin state court on the basis of a federal defense. ${ }^{77}$ The Kallen court justified its decision by noting that an action to vacate an award could as easily have been brought by the other party in an action to confirm the award. Because the action to confirm is within section 301(a), the court reasoned, jurisdiction should not depend upon who wins the race to the courthouse. ${ }^{78}$

75. 574 F.2d 723 (2d Cir. 1978).

76. Id at 726. In Varley v. Tarrytown Assoc., Inc., 477 F.2d 208 (2d Cir. 1973), the court disallowed removal in similar circumstances, noting that interstate implications of a contract are an insufficient basis to support section 301 jurisdiction. This holding was limited in 1/S Stavborg v. National Metal Converters, Inc., 500 F.2d 424 (2d Cir. 1974). Unlike Varley, Stavborg involved a collective bargaining agreement that contained a provision like the one in Kallen, that the arbitrator's award was to be "final" Id. at 426-27. See also Allendale Nursing Home, Inc. v. Local 1115, Joint Bd., 377 F. Supp. 1208 (S.D.N.Y. 1974) (allowing removal of suit to set aside arbitrator's award).

77. See Louisville \& Nashville R.R. v. Mottley, 211 U.S. 149, 152 (1908).

78. 574 F.2d at 725. 
The court's reasoning is logical, but the train of thought seems doomed for a head-on collision with Louisville \& Nashville R.R. v. Mottley ${ }^{79}$ The proper question is not who might have won a hypothetical race to the courthouse, but whether the plamtiff has alleged a federal claimin particular, whether he has alleged a violation of the collective bargaining agreement.

Discarding the well-pleaded criterion in favor of more attenuated policy concerns poses its own risks. For example, in Carillo v. Local 1115, Joint Board of Nursing Home \& Hospital Employees ${ }^{80}$ an einployer sought in state court to stay arbitration proceedings relating to the employer's alleged refusal to grant wage increases pursuant to the collective bargaining agreement. The union defendant removed the action to federal court. The collective bargaining agreement, however, prohibited either party from seeking removal to federal court of a state court action to compel arbitration. The court found that the question of the possible breach occasioned by the defendant's removing the suit was one for arbitration, since the contract required arbitration of disputes over any contract provisions. ${ }^{81}$ The court declared "the jurisdictional squabble . . . meaningless" and considered reinand to state court "wasteful and duphcative." 82 Since the only question before the court was which court, state or federal, would act, it is unclear why the remand would have been "duplicative" or "meaningless." In effect, the court allowed the defendant, by manufacturing a question of contractual breach in the act of removing, to determine the forum for deciding the arbitrability issue and to displace the plaintiff's state cause of action.

An allegation of the breach of a union's duty of fair representation does not necessarily give rise to federal jurisdiction under section 301 . The Court of Appeals for the Fifth Circuit in In re Carter ${ }^{83}$ recently stated that "a breach of the duty of fair representation is not always also a breach of the collective contract." 84 Hence the court found no basis to remove via section 301 an employee's suit alleging a conspiracy

\footnotetext{
79. 211 U.S. 149 (1908).

80. 441 F. Supp. 619 (S.D.N.Y. 1977).

81. Id at 621 .

82. Id.

83. 618 F.2d 1093 (5th Cir. 1980), cert. denied, 101 S. Ct. 1410 (1981).

84. 618 F.2d at 1104. See Medlin v. Boeing Vertol Co., 620 F.2d 957 (3d Cir. 1980) (action lur breach of duty of fair representation held non-reinovable where "bad faith" was not alleged); cf. UAW Local 375 v. Northern Telecom, Inc., 434 F. Supp. 331, 336-37 (E.D. Mich. 1977) (action for breach of duty of fair representation removable only in context of suit for breach of collective bargaining contract). But see Guaracino v. Communications Workers Local 2552, 330 F. Supp. 679,680 (E.D. Pa. 1971) (breach of duty of fair representation is breach of collective bargaining agreement within scope of section 301).
} 
by labor unions to deny him employment and union membership. The court did allow removal, however, based on the statutory duty of fair representation derived from sections $8(b)^{85}$ and $9(a)^{86}$ of the Labor Management Relations Act. ${ }^{87}$. Apparently then, a suit for breach of the duty of fair representation should always be removable pursuant to the alternate statutory grounds. Such a result cannot be expanded, however, to imclude within section 301 all collective-bargaining torts. ${ }^{88}$

At least one court has found a section 301 cause of action in a claim of infringement of constitutional rights. In Robbins v. George W. Prescott Publishing Co. ${ }^{89}$ a discharged employee sued his employer im state court on a claim, inter alia, that the employer had violated "a host of state and federal constitutional provisions." 90 The plaintiff alleged a private cause of action for imjunctive rehef and damages under state law. The federal court refused to remand this count of the complaint, holding that federal preemption under section 301 applied even though the complaint was couched in constitutional terins: "A contrary ruling would permit [the plaintiff] to make an end-run around the strong federal policy favoring resolution of labor disputes through the grievancearbitration mechanism."91 Yet the court refused to tackle the question whether this was in fact a section 301 dispute.

85. 29 U.S.C. $\S 158($ b) (1976).

86. Id. \& 159(a).

87. See 618 F.2d at 1104. Interestingly, in Carter the defendart, not the plaintiff, was seeking remand to state court. Upon removal to federal court, the plaintiff had made no objection to federal jurisdiction and had won a jury verdict in his favor. The defendant then sought to remand to the state court for lack of subject-matter jurisdiction. The district court ordered the case remanded. The circuit court's casting about for grounds to sustain federal jurisdiction probably reflects the court's disapproval of the defendant's acrobatic trial strategy. See also Grisbaum v. Meat Cntters Trust Fund, 482 F. Supp. 1218 (E.D. Wis. 1980) (basing removal jurisdietion on statutory dnty of fair representation).

88. See UAW Local 375 v. Northern Telecom, Inc., 434 F. Supp. 331 (E.D. Mich. 1977) (no section 301 jurisdiction for breach of implied duty of good faith and fair dealing in collective bargaining agreement negotiations). See also Coulston v. International Bhd. of Teainsters, $423 \mathrm{~F}$. Supp. 882 (E.D. Pa. 1979) (implication of doctrine of federal preemption does not create statutory federal-question jurisdiction in cause of action for malicious interference with employment). But see Nedd v. UMW, 556 F.2d 190, 198 n.12 (3d Cir. 1977), cert. denied, 434 U.S. 1013 (1978), holding that "a claim of tortions interference with a collective bargaining agreement by a Fund Trustee states a non-frivolous cause of action under $\$ 301$ of the Taft-Hartley Act sufficient to support pendent jurisdiction of state law claims in federal court."

89. [1981] LAB. L. REP. (CCH) I 12,816 (D. Mass. Nov. 14, 1980).

90. Id. at 17,785 .

91. Id, at 17,786. See also Fristoe v. Reynolds Metals Co., 615 F.2d 1209 (9th Cir. 1980) (complaint alleging violations of constitutional rights, aunong other common-law causes of action, was construed as alleging a breach of the collective bargaining agreement under section 301 , and hence was removable from state court). 


\section{B. Finding a Section 301 Contract.}

Section 301 specifically applies to "[s]uits for violation of contracts between an einployer and a labor organization representing einployees ... or between any such labor organizations . . .."92 Clearly this provision applies to contracts other than collective bargaining agreeinents. Its scope, however, is not sharply defined. In Textile Workers Union v. Lincoln Mills, ${ }^{93}$ the Court found that an agreenent to arbitrate, being the quid pro quo of a no-strike clause, was enforceable under section 301. Recently, the Supreine Court lield that a union constitution is a section 301 contract for purposes of invoking federal reinoval jurisdiction. In United Association of Journeymen v. Local 334, United Association of Journeymen, ${ }^{94}$ a parent union ordered nine of its local unions to consolidate. One of the locals filed suit in state court to enjoin the order, nnaking the complaint, inter alia, that the consolidation violated the union constitution. The parent union removed the case to federal district court. The Court of Appeals for the Third Circuit raised, sua sponte, the question of federal jurisdiction. ${ }^{95}$ The court observed that "the intent of Congress in enacting § 301(a) of the Labor Managenient Relations Act was to grant jurisdiction to the federal courts over suits based on contracts significant to the niaintenance of labor peace."96 Finding that the consolidation involved no "significant impact" on labor-inanagenient relations or industrial peace, the court determined that it lacked jurisdiction and remanded the suit to state court. 97

The majority opinion of the Supreine Court explicitly rejected the "significant impact" test applied by the Third Circuit. The Court deduced froin the sparse legislative history that Congress had intended not only to pronote industrial peace by stabilizing the collective bargaining process, but also to stabilize labor organizations by inaking thein legally accountable for agreenents entered into annong theinselves. ${ }^{98}$ The Court noted that appellate courts have long characterized union constitutions as contracts and that the prevailing view under

92. 29 U.S.C. \& 185(a) (1976).

93. 353 U.S. 448 (1957).

94. 101 S. Ct. 2546 (1981).

95. Local 334, United Ass'n of Jonrneynen v. United Ass'n of Jonrneynen, 628 F.2d 812 (3d Cir. 1980), rev'd, 101 S. Ct. 2546 (1981).

96. $628 \mathrm{~F} .2 \mathrm{~d}$ at 820 .

97. Id. The Court of Appeals for the Ninth Circuit also denands, as a prerequisite for federal jurisdiction, that the intra-union dispute affect external labor relations. See Lodge 1380, Bhd. of Ry., Airline \& S.S. Clerks v. Dennis, 625 F.2d 819, 823 (9th Cir. 1980); Washington Local 104 v. International Bhd. of Boilermakers, 621 F.2d 1032, 1034 (9th Cir. 1980).

98. $101 \mathrm{~S}$. Ct. at 2551-52. 
state law comported with that characterization. ${ }^{99}$ Furthermore, by not qualifying the term "contract" in section 301, Congress had evinced its intent to reach union constitutions as well as collective bargaining agreements. Therefore, the Court rejected the "significant impact" test as one that would "engage the Federal Courts in the sort of ad hoc judgments on the jurisdictional sufficiency of the pleadings that the unfettered language of $\S 301$ (a) belies."100

It is manifestly unclear, lowever, how a court is to determine that section 301(a) has been imvoked at all without judging the sufficiency of the pleadings, unless specific types of labor disputes have been previously corralled within the boundaries of section 301 by judicial fiat. But it is equally unclear how courts can practice judicial fiat except on an ad hoc basis. The Court appears, im fact, merely to have created greater jurisdictional uncertainty for disputes arismg just beyond the pale of Journeymen's facts.

In dissent, Justice Stevens noted that the Court had lost sight of the constitutional justification for Congress's regulation of collective bargaining agreements under the coininerce clause-the federal interest im maintaining industrial peace. To abandon the jurisdictional touchstone of the federal interest is to permit "the creation of federal law in a dispute implicating no federal imterest. Absent a limitation restrictimg $\S 301$ jurisdiction on the basis of the presence of a federal imterest or right, it will be difficult for district courts to determine what contracts are not encompassed by section 301."101

The jurisdictional determination thus becomes more, not less, ad hoc. The question arises, for instance, whether a dispute over a private contract between an employee and an employer falls within section 301. Absent a "significant impact" test, the only question would appear to be the coalescence of the private contract and the collective bargaining agreement. In Klepacky v. Kraftco Corp. ${ }^{102}$ laid-off truck drivers sued in state court for their employer's breach of a promise to provide thein with vested seniority on their milk routes. Although they alleged no breach of the collective bargaining agreement, removal was allowed: "While the plaintiffs[-]drivers may have been unknowledgeable of the principles of labor law and may lave been actually misled by their einployer to forego termination pay benefits, under the existing [bar-

99. In dissent, Burger, C.J., observed that state-court construction of union constitutions has "little bearing on the construction of the Labor Management Relations Act." Id. at 2554 n.4 (Burger, C.J., dissenting).

100. Id. at 2551 n. 10.

101. Id. at 2557 n.9 (Stevens, J., dissenting).

102. 80 L.R.R.M. 3144 (D. Conn. June 5, 1972). 
gaining agreement], any mdividualized side agreement . . . is merged in the written labor contract." ${ }^{103}$ Pursuant to national labor policy, the collective bargaining agreement was deemed to be the sole determinant of the plaimtiffs' rights. ${ }^{104}$

The Court of Appeals for the Third Circuit has taken a more restrictive view of relnoval jurisdiction based on private contracts. In Medlin v. Boeing Vertol Co. ${ }^{105}$ discharged employees sued for reinstateinent based on imdependent rights allegedly created by letters from their employer. The court held that the claim was removed improvidently from state court: although the collective bargaining agreement stipulated grievance procedures as the exclusive disposition procedure for all claims, that agreeinent "constituted no more than a backdrop for the plaintiffs' claim . . ..."106

Similarly, the question arises whether a pension plan dispute falls within section 301. In Sheeran v. General Electric Co. ${ }^{107}$ retired employees with vested pension benefits brought suit in state court seeking imcreased benefits. The Court of Appeals for the Ninth Circuit, holding the suit removable, found that the pension plan was an "imtegral part" of the bargaining agreeinent because the plan was "incorporated by reference in the labor contract."108 The Court of Appeals for the Third Circuit, on the other hand, concluded in Journeymen ${ }^{109}$ that "[a]lthough pension and welfare benefits are the product of collective bargaining, they are essentially autonomous trust funds established

103. Id. at 3146.

104. Id. Cf. Riley v. Letter Carriers Local 380, 485 F. Supp. 980 (D.N.J. 1980) (alleged oral agreement relating to provisions of collective bargaining agreement was sufficient to establish federal jurisdiction under 39 U.S.C. \& 1208(b) (1970), which provides federal jurisdiction for suits for violations of contracts between the Postal Service and labor unions representing postal employees).

It is not apparent from the opinion in Klepacky whether the court meant that the collective bargaining agreement explicitly encompassed all mdividual side agreements (no other reference is made to such a provision in the opinion) or whether the court is referring to provisions of the bargaining agreement requiring arbitration of all disputes. See 80 L.R.R.M. at 3145 n.l. The latter interpretation would also bring side agreements within the shadow of the bargaining agreement. Hence, either interpretation merges private contracts into the collective bargaining agreement as a basis of removal jurisdiction. Contra, Medlin v. Boeing Vertol Co., 620 F.2d 957 (3d Cir. 1980), discussed at text accompanying notes 105-106 infra.

105. 620 F.2d 957 (3d Cir. 1980).

106. Id. at 962. Cf. Pajares v. United Steelworkers Local 5769, 432 F. Supp. 418 (E.D. La. 1977) (no federal jurisdiction under section 301 for union officer's complaint that he had been demied semority privileges, for the contract allegedly violated was not a collective bargaining agreement, but rather a contract between the employee and the local union).

107. 593 F.2d 93 (9th Cir.), cert. denied, 444 U.S. 868 (1979).

108. 593 F.2d at 96-97. Accord, Rosen v. Hotel and Restaurant Employees \& Bartenders Union, 637 F.2d 592, 596 (3d Cir. 1981).

109. 628 F.2d 812 (3d Cir. 1980), rev'd, 101 S. Ct. 2546 (1981). 
under independent trust indentures." 110 The Supreme Court did not address this issue in Journeymen; apparently the issue must await further ad hoc judgments.

\section{Finding Appropriate Parties for a Section 301 Cause of Action.}

In determining federal removal jurisdiction, a court must consider not only whether the cause of action is founded on a violation of a section 301 contract, but also whether the parties are suitable for federal jurisdiction under section 301. A significant question in Journeymen is whether the dispute was in fact "between .... labor organizations" as section 301 requires. The Court finessed the issue. Undeniably, both a local union and its parent union are labor organizations, the Court observed. It is well settled that either a local or a parent may bring a case under section 301 . Therefore, the Court concluded, section 301 creates federal jurisdiction in a dispute between the local and the parent. ${ }^{111}$ That reasoning is eininently enthymemical, however, implying but not expressing that the local and parent are different labor organizations, not just aspects of a single entity, and that the dispute was between them rather than within a single organization. In dissent, Chief Justice Burger noted that a local is a "subordmate body" to its parent and that the union constitution, to the extent that it is a contract at all, is not a contract between the parent and locals, but nierely "between the union and its meinbers or among the members themselves . . . ."112 Further, the Chief Justice noted that the legislative history is devoid of any indication of congressional intent to subject interual union disputes to federal regulation. ${ }^{113}$

The question of appropriate parties for a section 301 action arises in a different context when pension and benefit fund trustees are parties

110. 628 F.2d at 820. Accord, Smith v. Hickey, 482 F. Supp. 644 (S.D.N.Y. 1979) (non-removable pension fund dispute did not turn on construction of collective bargaming agreement, but rather required interpretation of the pension contracts under state law).

For a canvassing of cases on each side of the issue, see Reiherzer v. Shannon, 581 F.2d 1266, 1270 (7th Cir. 1978). In Reiherzer the court sidestepped the issue of wheiher a pension benefit claim provides federal removal jurisdiction via section 301. That court found an independent basis for federal jurisdiction under sections 502(a)(1)(B) and 502(e)(1) of ERISA, 29 U.S.C. $\$ \S 1132(a)(1)(B),(e)(1)(1976)$, which provides federal and state jurisdiction over civil actions by participants to recover benefits under pension plans. Hence removal was allowed from state court. This holding was limited, however, to suits against pension trustees for improperly withholding benefits. 581 F.2d at 1271. See also Buczynski v. General Motors Corp., 456 F. Supp. 867 (D.N.J. 1978) (finding alternate bases of federal jurisdiction under section 301 and ERISA), vacated on other grounds, 616 F.2d 1238 (3d Cir.), cert. dismissed sub nom. Alessi v. Raybestos-Manhattan, Inc., 448 U.S. 911 (1980).

111. $101 \mathrm{~S}$. Ct. at 2549.

112. Id. at 2553 (Burger, C.J., dissenting).

113. Id. at 2553-54. 
to the litigation. For instance, when trustees of an employee benefit fund brought a state cause of action against trustees of an interrelated benefit fund, a federal district court would not sanction removal pursuant to section 301 regardless of whether the breach might liave impaired performance of the bargaining agreement, for neitler litigant was a party to that agreement. ${ }^{114}$ But when a trustee brought a state claim against an employer for failure to contribute to the trust fund as required by the bargaining agreement, another district court allowed removal. ${ }^{115}$ Even though the trustee was not a party to the bargaining agreenent, the essence of his complaint was the einployer's breacl of his contractual obligation. Because the fund's activities benefited both labor and manageinent, the court reasoned that the trustees could not be considered a component of an einployer association sumg another component of the association. ${ }^{116}$ Hence the claim alleged a contractual violation sufficient to invoke section 301 jurisdiction. ${ }^{117}$

\section{Toward Greater Jurisdictional Certainty}

Despite the Supreme Court's apparent adversion to ad lroc deterininations of section 301 jurisdiction on the pleadings, in many cases ad hoc determinations are inevitable. This is especially true when the plaintiff has commenced the action in state court without pleading a federal cause of action and the defendant seeks reinoval based on an imputed federal element. Close pragmatic judgments in individual cases, however, should not foreclose the development of clear jurisdictional standards for the class of cases as a whole. ${ }^{118}$ When the criteria of the well-pleaded complaint rule are relaxed, courts lose a useful tool for determining federal jurisdiction and inust grapple with questions of federal primacy and expediency while merely guessing at the federal interests implicated in the cause of action. ${ }^{119}$

When a court looks beyond the complaint to find a basis for removal, the ultimate determination of jurisdiction soinetimes seeins primarily a function of the court's willingness to promote federal forums for labor cases and to tiptoe about the pleadings to reach a conclusory

114. Smith v. Hickey, 482 F. Supp. 644 (S.D.N.Y. 1979).

115. Ziegler v. Howard P. Foley Co., 468 F. Supp. 221 (E.D. La. 1979). See also Lewis v. Benedict Coal Corp., 361 U.S. 459 (1960) (non-party trustees may enforce royalty provisions in federal court).

116. $468 \mathrm{~F}$. Supp. at 224.

117. See also New York Times Co. v. Rosenberg, No. 79-5504 (S.D.N.Y. Feb. 8, 1981) (allowing removal of suit by employer against union business agent for inducing a breach of the collective bargaining agreemeut).

118. See Cohen, supra note 33, at 908.

119. See id. 916. 
result. For example, in Lambright v. Red Ball Motor Freight, Inc. ${ }^{120}$ truck drivers sued im state court for back wages after the employer allegedly reduced the mileage allowance provided for in the bargaining agreement. Upon reinoval, the federal court could find no dispute over the terms of the contract, no disagreeinent between management and union, no need for federal expertise, and no question requiring a uniform national policy; therefore it remanded the suit to state court. The federal court saw only one issue: whether or not the hourly rates were reduced - a cause of action not governed exclusively by federal law. ${ }^{121}$ Interestingly, the court ignored the one consideration that would seein to bring the case directly under section 301: the plaimtiff's claim of a breach of the collective bargaining agreement.

In Talbot $v$. National Super Markets, 122 on the other hand, the court allowed removal of a state court claim for back wages by adopting a curiously negative approach: removal was allowed via section 301 because that section did not preclude the relief sought, because individuals are not barred from bringing suit under that section, and because the court could not know "whether the particular wage claim raised 'significant' issues of federal law without a thorough examination of the collective bargaining agreement and the facts giving rise to the claim."123 Such an approach effectively turns the well-pleaded complaint rule mside-out.

National labor policy must be protected efficiently, but Congress in enacting section 301 did not intend to supplant state jurisdiction. 124 Some labor-related conduct is not so closely interwoven with federally protected activity that state regulation of it would interfere with na-

120. 335 F. Supp. 28 (W.D. La. 1971).

121. Id. at 29.

122. 372 F. Supp. 1050 (E.D. La. 1974).

123. Id. at 1052-53.

124. See Dowd Box Co. v. Courtney, 368 U.S. 502 (1962); Jones v. General Tire \& Rubber Co., 541 F.2d 660, 663-64 (7th Cir. 1976); 93 CoNG. REC. 5146 (daily ed. May 12, 1947), reprinted in Senate Comm. on Labor \& Public Welfare, 93D Cong., 2D Sess., Legislative History OF THE LABOR MANAGEMENT RELATIONS ACT, 1947, at 1497 (1974) ("WW] give to employers the right to sue a union in interstate commerce, in a Federal court, for violation of contract. It does not go beyond that") (reinarks of Sen. Ball). See also 57 YALE L.J. 630 (1948) (questioniug constitutionality of section 30I because of its potential expansion of federal jurisdiction). Indeed, the Supreme Court at first held that the provisions of section 301 were only procedural in nature. See Association of Westinghouse Employees v. Westinghouse Elec. Corp., 348 U.S. 437 (1955). A decade after the enactment of section 301, however, the Court reversed itself and held im Textile Workers Union v. Limcoln Mills, 353 U.S. 448 (1957), that the provisions of section 301 werc substantive, authorizing federal courts to formulate a body of federal common law over labor disputes. Justice Frankfurter, in his long and vigorous dissent, noted that the legislative history of the Act did not support such a view and predicted that the majority's holding would generate conflicts between state and federal courts. Id. at $\mathbf{4 6 2}$ (Frankfurter, J., dissenting). 
tional labor policy. As Professor Wechsler has noted, "The problem is, therefore, to determine when relatively final state determination involves least risk of error upon federal matters, or when such risk as it involves is counterbalanced by the disadvantages of an original jurisdiction in the federal courts." 125 The question is the strength of the linkage of federal issues. No unqualified solution is possible. Some tests of jurisdiction, however, are more appropriate than others.

For mstance, it is too loose a test of federal removal jurisdiction to ask only whether the federal issue arises froin "a common nucleus of operative facts" of the collective bargaiming agreement, ${ }^{126}$ or only whether the claim speaks to the enforceability and interpretation of the collective contract. ${ }^{127}$ Such tests deinand only a hypothetical relationship between the claim actually brought and the federal claim that might be induced upon removal. Such tests invite endless inquiry into cause and effect. ${ }^{128}$

A nore appropriate test of removal jurisdiction asks whether a significant federal claim within the plain meaning of section 301 inheres and subsists in the complaimt. This test deinands a categorical rather than a hypothetical relation between the complaint and the federal issue. It closely resembles the traditional formulation of the wellpleaded complaint rule, but de-einphasizes the form of the coinplamt in deference to its substance. For removal jurisdiction to be invoked pursuant to section 301, this standard requires that there be an underlying violation, whether alleged or not, of the collective bargaming agreement or of a contract between labor organizations; that the parties to

125. Wechsler, Federal Jurisdiction and the Revision of the Judicial Code, 13 LAW \& CONTEMP. ProB. 216, 218 (1948).

126. This standard was advanced, for example, in Chapman v. S.E. Region I.L.G.W.U. Health and Welfare Recreation Fund, 265 F. Supp. 675, 679 (D.S.C. 1967).

127. See, e.g., Hayes v. C. Schmidt \& Sons, Inc., 374 F. Supp. 442, 445 (E.D. Pa. 1974) (allowing removal of profit-sharing dispute that hinged upon "the correct interpretation and application of the terms of the collective bargaining agreement"); Talbot v. National Super Mkts., 372 F. Supp. 1050 (E.D. La. 1974), discussed in text accompanying notes 122-23 supra. Cf. Cox, Some Aspects of the Labor Management Relations Act, 1947, 61 HARv. L. REv. 274, 305 (1948) ("It would be unfortunate if there should develop any strong tendency to look to the federal courts to settle questions concerning the interpretation and application of collective bargaining agreements").

128. Cf. Gully v. First Nat'1 Bank, 299 U.S. 109 (1936), in which Justice Cardozo remarked:

As in problems of causation, so here in the search for the underlying law. If we follow the ascent far enough, countless claims of right can be discovered to have their source or their operative hmits in the provisions of a federal statute or in the Constitution itself with its circumambient restrictions upon legislative power. To set bounds to the pursuit, the courts have formulated the distinction between controversies that are basic and those that are collateral, between disputes that are necessary and those that are inerely possible. We shall be lost in a maze if we put that compass by.

Id. at 118. 
the suit come properly within the purview of section 301 ; and that broad pohcy considerations be subordinated to the "real" claims raised in the plaimtiff's complaint. This standard would not necessarily resolve close questions like those raised in Journeymen. It would, however, imsist rightly upon an inquiry into the federal interests involved in a state cause of action for which removal is sought and would inhibit the deliquescence of a holding such as Journeymen's into cases arising about its factual confines. Sucli a standard would preserve the interests of litigants, foster national labor policy, and inject a modicum of certainty into an area suffering from a lack of it.

\section{CONCLUSION}

Professor Colien has noted, "The 'well-pleaded' requirement will not yield to good, pragmatic reasons for rejecting it in individual cases or groups of cases." 129 It is disturbing, then, to find the Court of Appeals for the Ninth Circuit declaring dogmatically that " $[t]$ he court's recharacterization of [the employee's] complaint . . . is required by federal preemption doctrines." 130 Perhaps the court merely misspoke itself, for the process of recharacterizing a state claim as federal is clearly antecedent to and independent of the process of finding that claim preempted. But the statement is characteristic of the question-begging stance often adopted by courts in determining reinoval jurisdiction in labor cases. If the origimal claim does not invoke federal jurisdiction, explicitly or implicitly, then "recharacterization" of that claim is hardly justifiable and certainly not required. The proper concern should be whether federal law encoinpasses the cause of action, not whether the plaimtiff might have couched his claim in terms of federal law. If competing rights and policies appear equiponderant, then in fairness to the plaintiff, state jurisdiction should prevail. ${ }^{131}$

The well-pleaded complaint rule is no sterile fornality. ${ }^{132} \mathrm{Re}-$ laxing its requirements serves only to efface the boundaries of federal jurisdiction.

Michael B. Thornton

129. Cohen, supra note 33, at 915.

130. Fristoe v. Reynolds Metals Co., 615 F.2d 1209, 1212 (9th Cir. 1980), discussed at note 91 supra.

131. Some courts have insisted that if any doubts arise about removability, those doubts should be resolved in favor of remand. See Butler v. Polk, 592 F.2d 1293 (5th Cir. 1979); Sepia Trucking Co. v. International Bhd. of Teamsters Local 705, No. 80 C 403 (N.D. Ill. July 31, 1980); WRIGHT, Miller \& COOPER, supra note $13, \S 3721$, at 535-36 and cases collectcd therein.

132. Skelly Oil Co. v. Phillips Petroleum Co., 339 U.S. 667, 673 (1950). 